\title{
伊良湖西の浜海岸の海岸過程に関する考察 \\ Coastal Process in IRAGO-NISINOHAMA Beach
}

村上宗隆*・青木慎悟**・岩田好一朗***

Noritaka MURAKAMI, Shingo AOKI and Koichiro IWATA

\begin{abstract}
The characteristics of coastal process in IRAGO-NISINOHAMA beach are discussed in this paper. Since this coast has been eroded, several protection works against beach erosion have been done. The northerly sediment transport can be found to be caused by the winter wind from the western-side directions. Moreover, the wind waves from the Pacific Ocean caused by the typhoons encourage the northerly sediment transport. The detached breakwaters and groins work effectively for IRAGO-NISINOHAMA beach.

Keywords : coastal process, sediment transport, winter wind
\end{abstract}

\section{1. 序論}

近年, 日本各地で海岸地域の開発と保全が行われているが, 旧来と異なり海岸地域の環境創造に力点が置かれる様 になり，親水利用計画の観点から言えば，その中核をなすのが砂浜である．砂浜は，固有のやすらぎ空間を提供する ばかりではなく，消波，水質净化等の種々の機能を有していることから，今後砂浜に対するニーズは増し，砂浜の維 持・復元・創出を目的とした構造物の設置が予測される.

養浜・砂浜の保全を目的とした対策工法を施工する際，構造物自体の安定性については，確率風速等を用いた設計 波浪による耐波設計が精度高く行われているが，構造物設置に伴う地形変化量の評価，つまり形成される砂浜の定量 的な評価は必ずしも満足のいくものとは言い難い，正確な地形変化を予測するためには，対象とする現地海岸の特性 を把握すると共に，漂砂の連続性といっ た海岸過程に関する事象をも把㩧する必 要がある. 本研究では, 伊良湖西の浜海 岸の海岸過程について考察する.

\section{2. 伊良湖西の浜海岸の概要}

伊良湖西の浜海岸は, 愛知県渥美郡渥 美町地先にあり, 渥美半島の西端に位置 する延長約 $7 \mathrm{~km}$ の直線海岸である. 西の 浜海岸一体の地質は, 砂壤土, 壤土が散 在し, 酸度が強く, 有機質に乏しい沖積 層に属している．この沖積層は, 西の浜 砂础帯あるいは西の浜砂嘴とよばれる完 新世に形成された砂浜, 砂丘列とされて (る ${ }^{1)}$ 。これらの砂琲帯は，浻岸流によ り，遠州灘からの侵食・運搬物質により 形成されたと考えられている.

西の浜の背後地は, 昭和 21 年に農林省 直轄伊良湖開拓建設事業として, 旧陸軍 試射場を開拓して以来現在に至るまで, 農地として利用されてきた. 開拓当時は, 遠浅の砂浜からなる自然海浜が形成され ていたか，昭和 34 年の伊勢湾台風の高潮

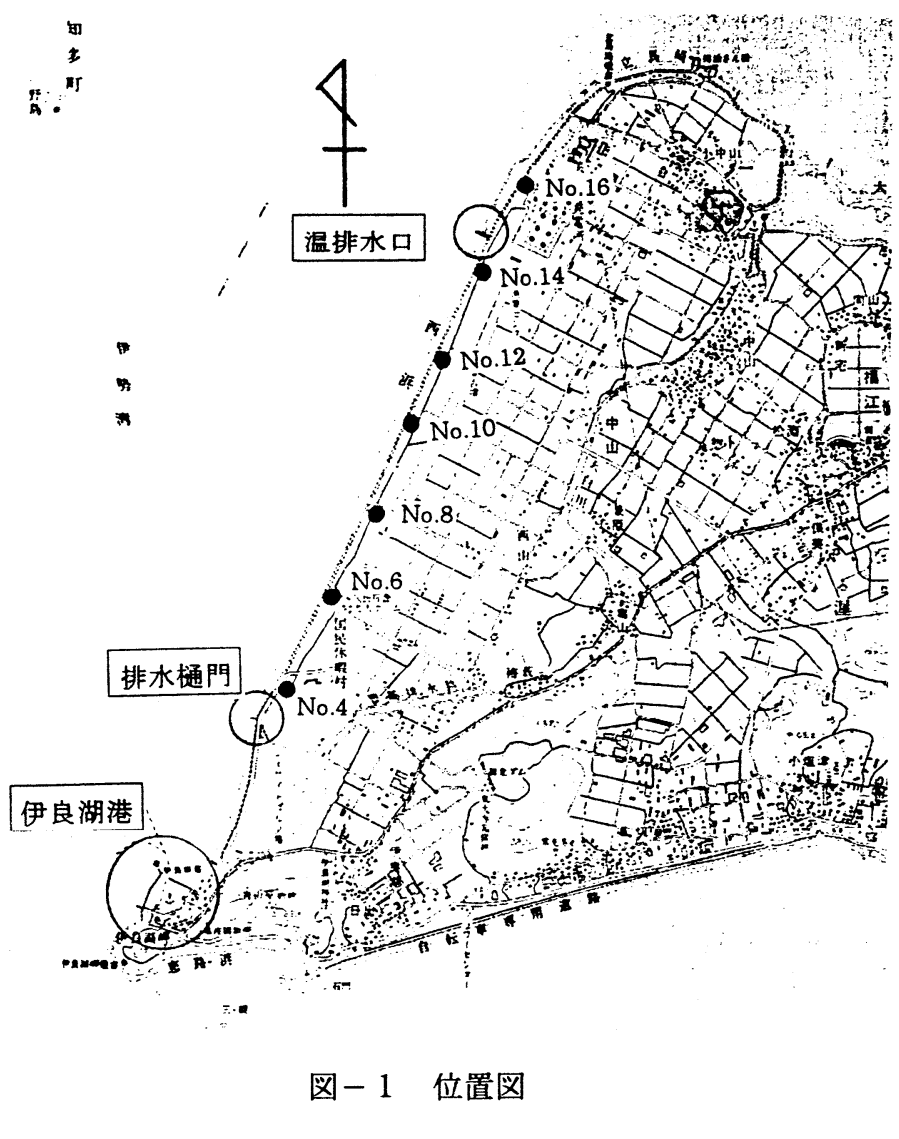

\footnotetext{
* 正 会 員 玉野総合コンサルタント株式会社 設計第 1 部第 2 課(テ464 名古屋市千種区豊年町 9-20) 
により, 西の浜海岸総延長䄪 $11 \mathrm{~km}$ の内 $60 \%$ にあたる約 $7 \mathrm{~km}$ が堤内地への海水の浸入を許し, 開拓地に甚大な被害 をもたらした．そのため，次年度より炎害復して高潮対策事業が着手され，昭和 39 年までに，西の浜海岸全域は，三 面コンクリート舗装高潮防波堤(基礎工 : 3.0 mのコンクリート矢板)で覆われることとなる.

高潮堤設置時点では, その前面に 50 100 mの砂浜が残っていたが, 年々侵食が進み, ついには高潮堤の基礎工が 露出する被害が生じた. そのため, 昭和 50 年以降, 基䃈工前面に吸い出し防止の鎆矢板が打設された. さらに, 昭和 53 年以降には, 砂浜の侵食が顥著となり, 海岸保全事業として, 離岸堤(離岸距離 : 40 50 m)が建設されされ, 現在 に至っている.

\section{3. 海岸構造物の遷移}

西の浜海岸では, 前出の高潮堤の他に, 色々な海岸構造物が設置されてきた，構造物の設置により漂砂環境が大き く影響を受け，その結果，汀線形状が変化したことが予測される.

(1)伊良湖港の建設

伊良湖港は, 伊良湖岬の伊勢湾側(西の浜の南端)ある港で, 1948 年(昭和 23 年)に建設が始まり, 1957 年(昭和 32 年)にはほほ現在の形状になっている(図-1 参照). 伊良湖港の南側に造られた全長約 $550 \mathrm{~m}$ の防波堤は，伊良湖岬 の先端から回り込む漂砂を遮る位置にある．西の浜で最初に

離岸堤が設置された個所か，伊良湖港の北側であったことを 考えると,この防波堤によって, 沿岸漂砂は少なからず遮ら れたと判断できる.

(2)排水樋門の設置

背後に広がる農地の湛水防除事業か，高潮対策事業之並行 して進められ，1964 年(昭和 39 年)に排水桶門が完成した. 排水樋門には，長さ約 $60 \mathrm{~m}$ の導流堤が併設されており，さ らに，樋門の設置位置は，図-1に示す通り，地形的に若干 尖った先端部分に設置されているため, 沿岸方向の漂砂がそ の影響を受けると予測される，そのため，樋門設置以後，樋 門の北側(漂砂下手側)の汀線は, 後退しているのに対し. 樋 門の南側(漂砂上手側)の汀線は逆に，前進していることが， 航空写真よりわかる.

(3)温排水放水路の設置 中部電力渥美火力発電所は，西の浜海岸の北側に位置し， 温排水の放水口が, 沖合い約 $70 \mathrm{~m}$ の地点まで延びている. この放水口屯樋門之同様に，北向きの漂砂に影響を与える結 果となり, 漂砂上手侧での汀線の前進, 下手㑡での汀線の後 退が確認できる.

(4)離岸堤の設置

1978 年(昭和 53 年)から, 侵食対策構造物として, 消波ブ

\begin{tabular}{|c|c|}
\hline 表一 & 構造物設置の時系列 \\
\hline 年 度 & 事 \\
\hline (昭和初期) & 遠浅の秒浜 \\
\hline 1943(昭和 21 年) & 農地開拓事業始まる( 1965) \\
\hline 1948(昭和 23 年) & 伊良湖港の建設始まる( 1957) \\
\hline $\begin{array}{l}1959 \text { (昭和 } 34 \text { 年) } \\
1960 \text { (昭和 } 35 \text { 年) }\end{array}$ & 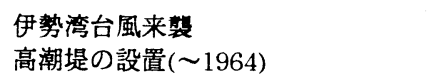 \\
\hline 1964 (昭和 39 年) & 伊良湖樋門の完成 \\
\hline 1968 (昭和 43 年) & 発電所温排水放水路 $(1,2$ 号機)の建設 \\
\hline $\begin{array}{l}1975 \text { (昭和 } 50 \text { 年) } \\
1978 \text { (昭和 } 53 \text { 年) }\end{array}$ & 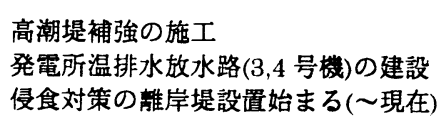 \\
\hline 1994(平成 5 年) & 堆砂を目的とした離岸堤の設置 \\
\hline
\end{tabular}
ロックを用いた離岸堤が設置されてきた，被災箇所，もしく は被災する可能性の高いところから順次施工されてきたが，概ね，伊良湖港付近から徐々に北に向けて設置されて いる様に見られる. また, 南側の立馬㥓付近の離岸堤も，同様に南側から順に施工されている様に見受けられる. 侵食の激しい地点では, 既設離岸堤の海側に, さらにもう1列離岸堤を設置した例もある.

\section{4 . 風と波の特性}

伊良湖西の浜海岸に来襲する波浪の特性について, 現地での波浪観測テータが無いため, 詳細な風況観測デー夕を 基に推測するものとする.

風況は，西の浜海岸の背後にある国民休暇村で観測された，1988 年(昭和 63 年) 12 月から 1993 年(平成 5 年) 12 月 までの観測データを用いる．欠測を除く全観測時間に対する風向別風速別の出現率を，図ー2に示す． $6 \mathrm{~m} / \mathrm{sec}$ 以下の 比較的小さい風速の出現率は， $\mathrm{E}$ 方向とW方向にピークがあり，その頻度は，ほぼ同じであることがわかる．それに 対して $6 \sim 12 \mathrm{~m} / \mathrm{sec}$ の比較的大きな風速は，W方向に集中しており, WSW NW の 4 方向の風が全体に対して $26 \%$ を占める. こ机らは，冬期の強い季節風が卓越する風況と，夏季の弱い東風が卓越する風況に起因する. 

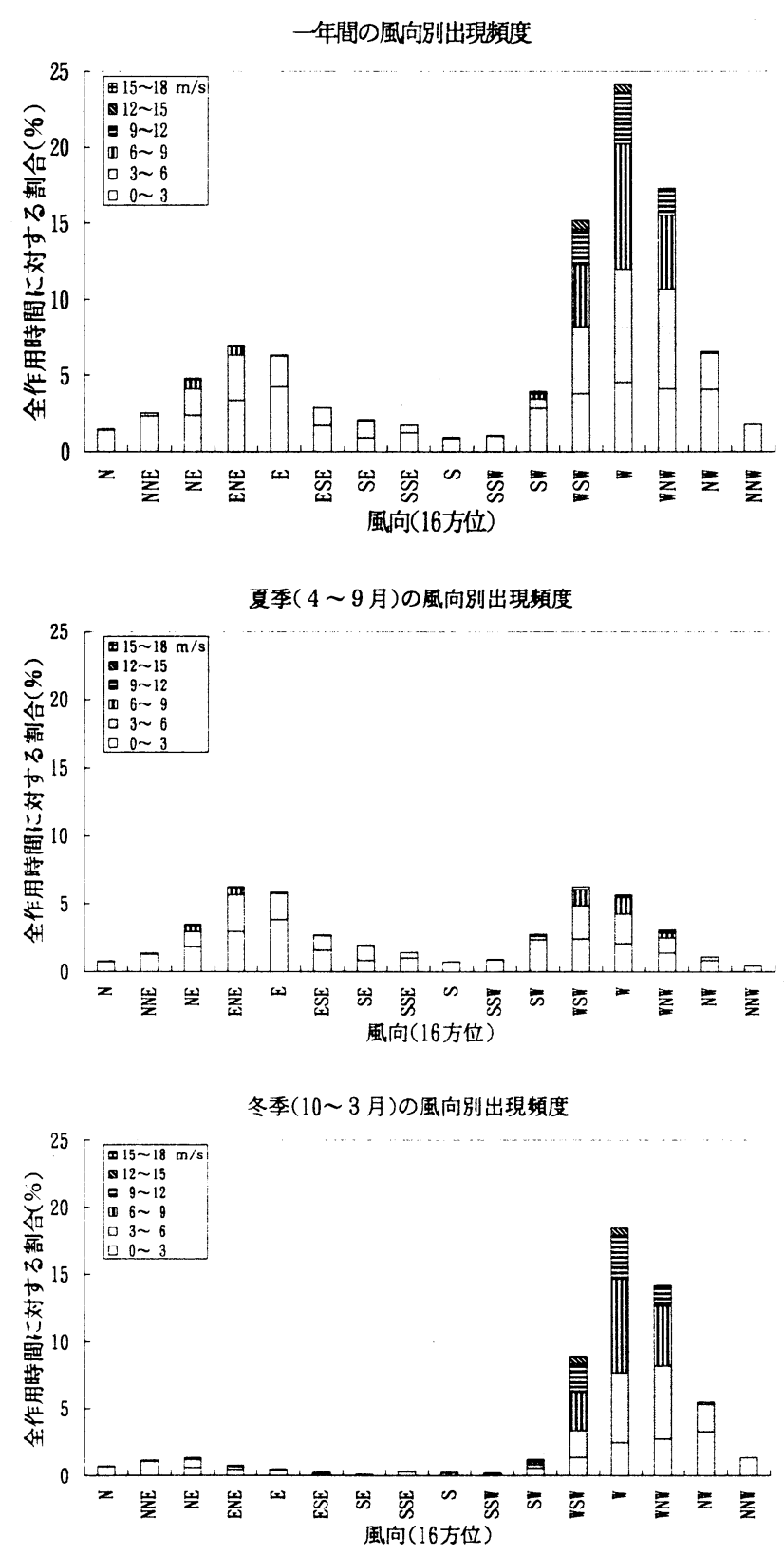

図 -2 風向別の出現頻度

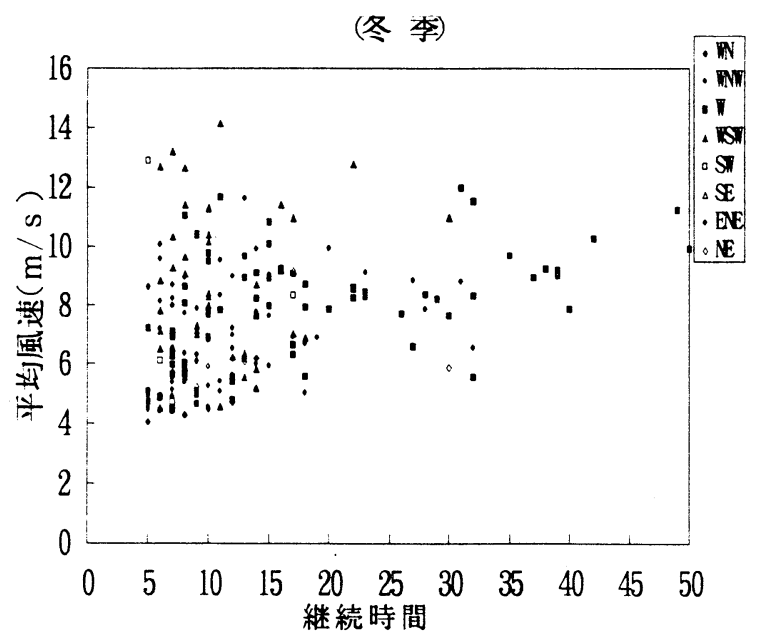

冬季（10月～3 月）は, W-WNW 方向からの強い季 節風が卓越し，西の浜海岸に海側から吹く風が， $93 \%$ を占める. 比較的弱い風の風向は NW 方向に分布し, 風速が大きくなるにつれて，W 方向にその分布を移す ことが分かる. 夏期 (4月～9 月) の風は, $\mathrm{E}$ 方向の弱 い風が多く卓越し, $N E \sim S$ 方向の風は, 夏季の観測時 間の $61 \%$ を占め, $\mathrm{SW} \sim \mathrm{N}$ 方向の西風の $35 \%$ を上回っ ている. この風は，0〜 $5 \mathrm{~m} / \mathrm{sec}$ が $74 \%$ を占める比較的 弱い風である.

風の特性のもう一つの要素として, 風向別風速別の 継続時間を取りあげる.ここで, 現地の風は刻一刻と 複雑に風向・風速が変化するため, SMB 法で波浪を 算定することを念頭に置き，(i)有義波高が吹送距離に 依存する継続時間(約 5 時間)よりも短い時間で風向が 变わる場合には，継続時間として取り扱わない，(ii) 風向が 16 方位で 3 方向程度に, 数時間毎ふらつく場 合は，その中心方向の継続時間としてカウントする, の 2 つの仮定を用いて風を整理した後, 継続時間を求 めた．なお，デー夕を整理した期間は 1994 年(平成 6 年)の一年間である.

風向別の継続時間と各継続時間内の 2 乗平均風速の 散布図を図ー 3 に示す. WNW SW 方向は，ある程 度強い風速を保ったまま, 5 時間以上吹いた後風向が 変動するケースが多いため, 本研究で用いた分類では, 継続時間が短くても，2乗平均風速が大きいケースが 存在する結果となる. しかし, 風の群を 1 つの風之判 断すると, 風向を問わず吹送時間が長くなるにつれて 2 乗平均風速も大きくなり，ほぼ 1 つの直線に近似で きるような分布である. 風向別には $35 \sim 50$ 時間と長 い継続時間を示す風は, 冬期の W 方向に多い。これは, $\mathrm{W}$ 方向を中心として WSW WNW 方向の間を変化す る, 強くて長い風が多いことが要因として挙げられる. 東方向の風の継続時間の特徴は, 春期後半から夏期に かけてが若干長く, 季節は夏季に多い。 また, 強風は

図-3 風向別の吹送時間と風速の相関 
台風でない限り吹かないため, 継続時間も 20 時間未満の ものが多大半を占めている.

以上の風況を用いて, 波浪波浪推算を行う. 直線海岸 である西の浜海岸の法線方向がWNW 方向であること等 を考慮し, SW-NW の 5 方向を取りあげる. 1994 年度(平 成 6 年度)の風向別波高別の出現頻度をこの 5 方向に限っ て示したのが, 図ー4である.この 5 方向の内, WSW〜 WNW 方向の 3 方向の出現頻度は $95 \%$ を占めており, W 方向の卓越が非常に強いことがわかる．また，有義波高 $1 \mathrm{~m}$ 以上の波は WSW WNW 方向の 3 方向のみから, 冬期に生じるている. 有義波高が $30 \mathrm{~cm}$ 以上となる波浪 は, $\mathrm{SW} \sim \mathrm{NW}$ 方向のみである.

また，風況をモデル化する場合は，図-2より，1.年間 を通して同一の風況を与える場合之，2. 冬季亡夏季に分 けて風況を与える場合の 2 種類の条件に分けることがで きる，各々のケース毎に平均風速を計算 し，S M B 法により求めた波浪の条件を 表 -2 に示す. 今回の試算は, SMW 法の 範疇を越えない議論である，実際には， 夏季の台風等の挸乱を考慮して検討する 必要があるが,これについては, 後日別 の機会に報告する予定である.

\section{5. 地形変化特性}

航空写真による長期的な汀線変化特性 は，前節で述へた。.ここでは，梁浅測量結 果より算出した地形変化量を用いて, 実際 の海底地形変化ついて検討を加える. 地形 変化量を考慮する範囲は, 汀線変動の著し い伊良湖樋門以北とし，対象亡する期間は， 養浜目的で離岸堤が設置された平成 2 年 度以降の期間(平成 2 年(1990)10 月, 平成 4 年(1992) 12 月, 平成 6 年(1994) 10 月の等 深浅図を使用)である.

地形変化量の算出は, 沖合い $250 \mathrm{~m}$ 地点 までを $12.5 \mathrm{~m}$ のメッュに区切り, 各メッ シュ毎の平均水深の変化を等深浅図より 読み取り，その值に各メッシュの面積を乗 じて浸食・堆皘量を算出した。なお，250 mは，横断図の重ね合わせより推定した移 動限界水深を与える位置である.

計算区間全体におけるトータルの土砂 浸食・堆積量は, 平成 2 年(1990) 平成 4 年(1992)の 2 ヶ年では, 15 万 $\mathrm{m}^{3}(/ 3.15 \mathrm{~km} /$ 2 年)堆積しているのに対して, 平成 4 年 (1992) 平成 6 年(1994)の 2 ヶ年では逆に, 18 万 $\mathrm{m}^{3}(13.15 \mathrm{~km} / 2$ 年)侵食されている. この原因として，台風の影響が考えられる. 表一 2 に, 各年度の测量時期と, 測量時期 以前に来䘫した台風( 2 ヶ月以内)を示す.
表一2 SMB 法により求めた波浪条件

\begin{tabular}{|c|c|c|}
\hline ケース & 平均波高 & 周期 \\
\hline 夏季( 4 月〜 $~ 9$ 月 $)$ & $0.35 \mathrm{~m}$ & $2.3 \mathrm{sec}$ \\
\hline 冬季(10月〜3月) & $0.55 \mathrm{~m}$ & $2.9 \mathrm{sec}$ \\
\hline 通年 & $0.40 \mathrm{~m}$ & $2.5 \mathrm{sec}$ \\
\hline
\end{tabular}

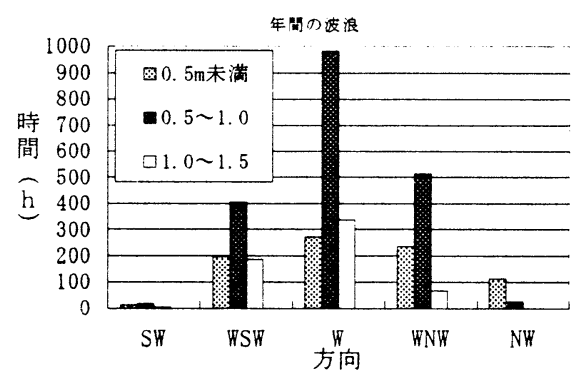

図-5 風向別波高別の出現頻度

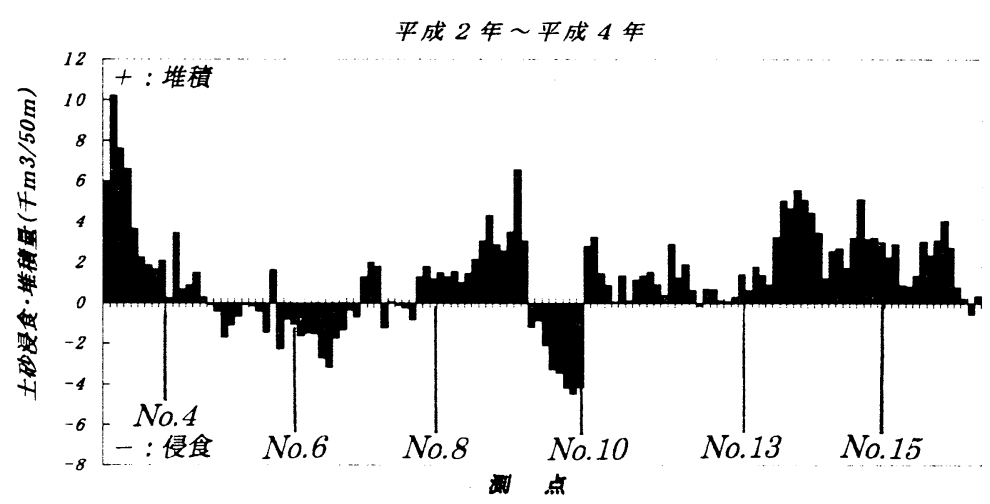

(a)

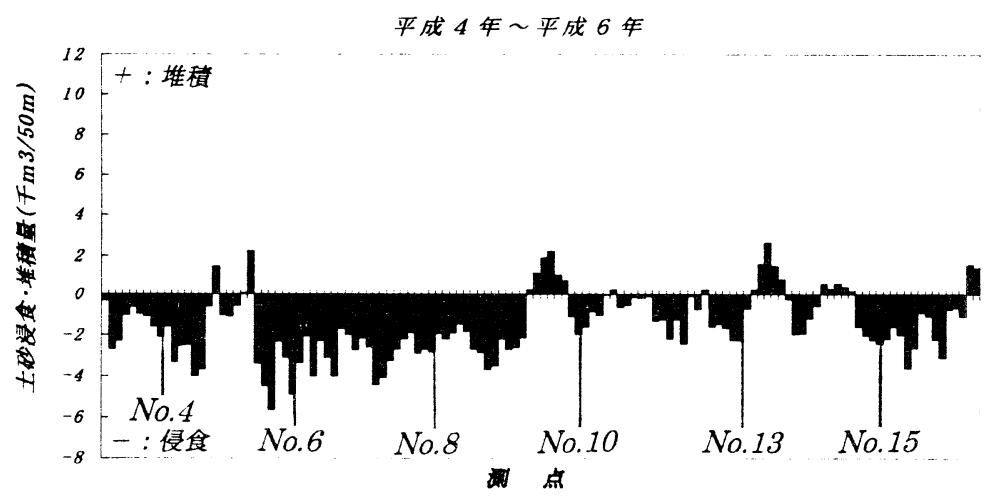

(b)

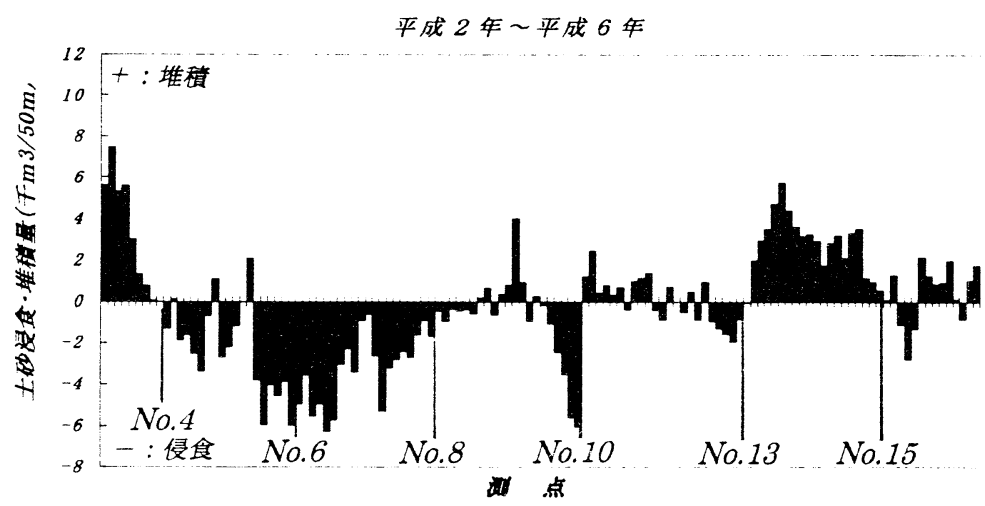

(c)

図-5 平成 2 年 平成 6 年までの測点毎の土量の変化 
平成 4 年(1992)には，測量時期に台風は来襲 していないのに対して，平成 2 年(1990)と平 成 6 年(1994)には, 測量時期の直前に台風が 来襲している. その結果, 平成 2 年(1990) 〜平成 4 年(1992)では，平成 2 年(1990) 9 月 に来襲した台風によって生じた侵食が埋戻 されることにより，全体では堆積を示し，また，平成 4 年(1992) 平成 6 年(1994)では，平成6 年(1994) 9 月に来襲した台 風による侵食が現れたと考えられる.

平成 $2 \sim 4$ 年までの地形変化量(図一 5 (a))より, No.4 付近の堆積は，樋門北側に設置された離岸堤に砂がトラップされ たことによる. 航空写真を見ると，何らかの影響で平成 2 年当時の No.9〜 10 付近の汀線が周辺に比べて凹型になっており, その不陸を平滑化するへく No.9〜10 付近の堆積と侵食が生じたと考えられる. また, No. $13+200$ 付近の堆積は, 離岸距離 約 $150 \mathrm{~m}$ 付近の沿岸砂州沖側の, 水深 8 11 m付近の比較的深い水深での土砂の堆積に起因する.

平成 $4 \sim 6$ 年の変化(図 -5 (b)) より, 全体的に侵食傾向であることがわかるが, 平成 5 年 12 月以降、No. $4+425$ 地点に 施工された突堤周辺では侵食量が押さえられていることがわかる. しかしながら併設された離岸堤(No.5+300〜 Na.6)の北側 は, 離岸堤の回折波の影響を受け，侵食を呈している. その侵食砂は離岸堤背後に流入したと考えられるが, 離岸堤背後の 汀線付近にある既設離岸堤(異形ブロック皘)の撤去に伴う地盤高の低下のため, 顕著な堆積量は生じていないように見える.

平成 $2 \sim 6$ 年の 4 年間の地形変化より, 既設離岸堤への堆積(No.4 付近), 新設離岸堤による侵食・堆積(No.5+300〜No.6) といった, 構造物に起因する地形変化量が大きい. このことは, 西の浜海岸では沿岸漂砂が極めて卓越していることを示し ている.

No. $4+300 \sim$ No. $6+200$ の $900 \mathrm{~m}$ の 区間は, 平成 5 年(1993) 12 月〜平成 6 年(1994) 6 月に突堤が, 平成 5 年 (1993) 8 月〜平成 6 年(1994) 1 月に突 堤北側の 1 基目の離岸堤が, さらに平 成 6 年(1994) 8 月からその北側に 2 基目の離岸堤がそれぞれ施工された 区間であり，漂砂の移動が大きいと考 えられるため, 深浅測量テータを用い てさらに詳細に検討した.

同区間の平成 2 年(1990) 平成 4 年(1992), 平成 4 年(1992) 平成 6 年 (1994)の地盤高の変化量を図一6に 示す。図一 6 (a)は, 平成 2 年(1990) の地盤高に対する平成 4 年(1992)の 地盤高を、図一 6 (b)は，平成 4 年 (1992)の地盤高に対する平成 6 年 (1994)の地盤高をそれぞれ示してい る. なお, 同図の離岸距離は高潮堤か らの距離である. 突堤・離岸堤の施工 前である平成 2 年(1990) 平成 4 年 (1992)における地形変化の特徵とし て, 図一6(a)より，高潮堤から沖に $50 \mathrm{~m}$ までの区間(水深 $1.5 \mathrm{~m}$ 以浅およ び陸域）全体において、地盤高は平均 で約 $30 \mathrm{~cm}$ 下がっている(約 $15,000 \mathrm{~m}$ ${ }^{2}$ が浸食) のに対し, 離岸距離 $50 \mathrm{~m}$ 付近から沿岸砂州 $(150 \mathrm{~m}$ )までの区間（水深 $1.5 \mathrm{~m} \sim 3.5 \mathrm{~m}$ ) において、地盤高は平均 で約 $10 \mathrm{~cm}$ 上がっている（約 $8.600 \mathrm{~m}^{2}$ が堆積）.

また，突堤・離岸堤建設された，平成 4 年(1992)から平成 6 年(1994)までの, 構造物周辺における地形変化の特徵として, 漂砂の上手側である突堤南側では, 地盤高が平均で約 $30 \mathrm{~cm}$ 上がっている(約 $1,800 \mathrm{~m}^{2}$ が堆皘)のに対し、漂砂の下手側であ る突堤の北側では, 汀線から $75 \mathrm{~m}$ 沖合いまでの範囲で, 地盤高が平均で約 $40 \mathrm{~cm}$ 下がっている(約 $3.300 \mathrm{~m}^{2}$ が侵食)ことが (a) 平成 2 年 平成 4 年

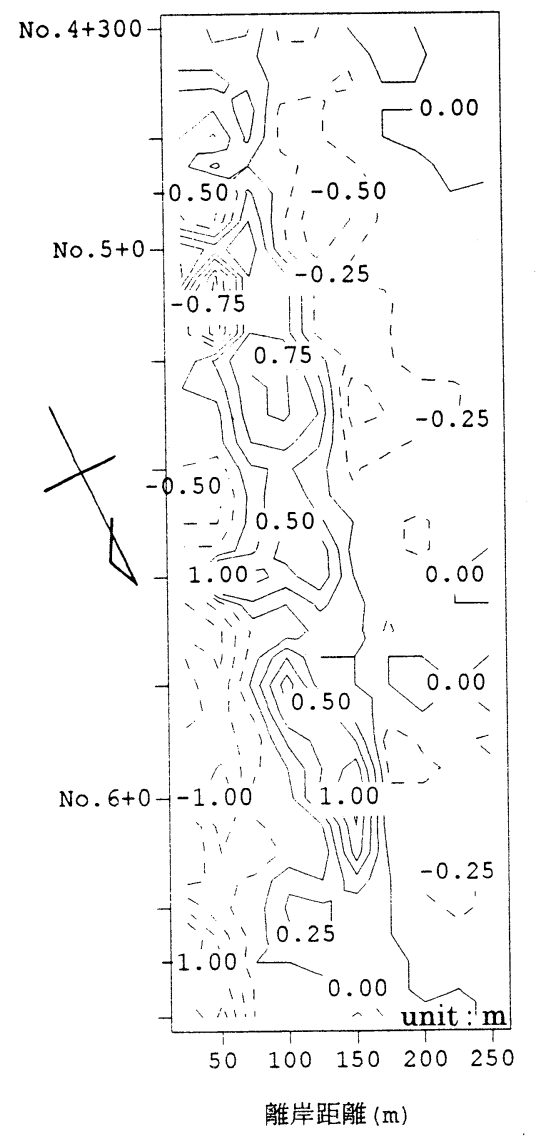

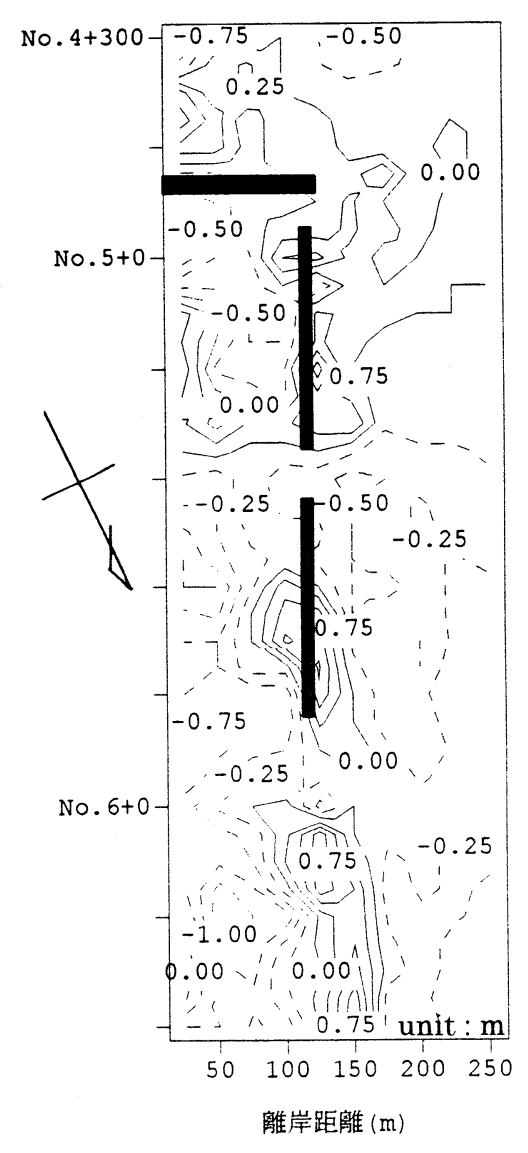

(b) 平成 4 年 平成 6 年
図 -6 地盤高の変化量 
挙げられる. 突堤に近い離岸堤の背後全体では，離岸堤中央よりやや北寄りに侵食部分が小さい, トンボロ地形が形成され つつていると判断できる箇所はあるものの、離岸堤の背後では，地盤高が平均で約 $10 \mathrm{~cm}$ 下がっている(約 $2.200 \mathrm{~m}^{2}$ が浸食). 北側の離岸堤は，完成時からの日数が少ないため、離岸堤による地形変化の影響はほとんど出ていない，しかし，地盤高 は全体的に低下傾向にあり，汀線付近で約 $60 \mathrm{~cm} 、$ 沿岸砂州付近までが約 $10 \mathrm{~cm}$ 、沿岸砂州より沖についても約 $26 \mathrm{~cm}$ 地盤高 が下がている. このように短期的な地形変化で見ると, 離岸堤背後も平均的には浸食されているが, 浸食量は減少してト ンボロ地形が形成されつつある様子が何えるため,養浜等の対策を行えば早期にトンボロを形成し静的に安定した砂浜が維 持されていくことが予想される.

\section{5 結論}

\section{本研究で得られた主な結論を以下に示す。}

・伊良湖西の浜は，侵食性の自然海岸であり、全体的に経年的な汀線後退を起こしてきた。

・現地の風は、特に冬季において西方向から風速 $10.0 \mathrm{~m} / \mathrm{s}$ 以上の強い季節風が多く卓越し、その継続時間は平均で約 20 時間である。

・冬季には波高 $1.0 \mathrm{~m}$ を越える高波浪が長時間作用し、出現時間は $\mathrm{W}$ 方向をピークとして波高 $30 \mathrm{~cm}$ 以上の波浪に限ると、 その波高はWSW〜WNW 方向が $90 \%$ 以上を占める。

- 西の浜海岸では北向きの沿岸漂砂が卓越しており、伊良湖防波堤・樋門・中部電力渥美火力発電所放水口といった海岸 構造物により北向きの沿岸漂砂は遮断され、それぞれの構造物の漂砂下手側である北側において汀線後退が見られた。

- 離岸距離 $40 \mathrm{~m} \sim 80 \mathrm{~m}$ の位置に施工された離岸堤は，汀線付近に限って言えば，堆積に効果があった．また，平成 5 年 以降, 離岸距離 $130 \mathrm{~m}$ の位置に離岸堤が施工され，離岸堤背後の侵食量は減少し今後堆積に転じると推測される。

なお, 本論では, 地形変化量について考察してきたが, 著者等は別途数值解析によりこの伊良湖西の浜の海浜地形の予測 計算を既に行っており，数值計算結果と実測結果のつき合わせ結果については別の機会に報告する予定である.

最後に, 本研究を行うにあたり，伊良湖西の浜地区の風のテータ，および深浅測量結果といった貴重なテー夕を提供して いただいた，愛知県農地林務部豊橋農地開発事務所に対して，感謝の意を表します.

6. 参考文献

1) 日本全国沿岸海洋誌, 日本海洋学会沿岸海洋研究部会編, 東海大学出版会 